\title{
Pengembangan Bahan Ajar E-Book pada Mata Pelajaran Praktikum Akuntansi Perusahaan Manufaktur
}

\section{The Development of E-Book Teaching Materials on the Subjects of Manufacturing Companies Accounting Practicum}

\author{
Aprilyana Eka Saputri \& Joni Susilowibowo \\ Universitas Negeri Surabaya, Surabaya, Jawa Timur, Indonesia \\ aprilyanasaputri16080304063@mhs.unesa.ac.id
}

Naskah diterima tanggal 07/07/2020, direvisi akhir tanggal 11/08/2020, disetujui tanggal 30/08/2020

\begin{abstract}
Abstrak
Bahan ajar $e$-book ialah produk dari penelitian ini. Penelitian ini adalah jenis penelitian pengembangan. Bahan ajar e-book yang diterapkan dipenelitian ini menggunakan pendekatan saintifik. Mata pelajaran dalam penelitian ini ialah Praktikum Akuntansi Perusahaan Manufaktur, pada materi pencatatan dan pengikhtisaran. Beberapa tujuan yang ada yaitu untuk (1) Menganalisis bagaimana runtutan pada pengembangan bahan ajar e-book; dan (2) Menganalisis apa yang dihasilkan dari penelitian pengembangan ini. penelitian pengembangan mengambil dari model 4D Thiagarajan. Jenis dari penelitian ini ialah penelitian R\&D (Reseacrh and Development). Namun, batasan pada penelitian ialah hanya dilakukan sampai Develop (Pengembangan). Subjek dari penelitian ialah beberapa dosen para ahli dan salah satu guru mata pelajaran praktikum akuntansi perusahaan manufaktur. Responden yang terdapat pada penelitian ini ialah peserta didik kelas XII program keahlian Akuntansi Keuangan dan Lembaga SMK Negeri 1 Sooko Mojokerto yang berjumlah 20 siswa. Hasil penelitian dari beberapa ahli menunjukkan beberapa komponen, yaitu kelayakan isi 89,22\% dengan kriteria "sangat layak". 92,10\% dengan kriteria "sangat layak" didapat dari aspek penyajian. Komponen kebahasaan didapatkan presenatse sebesar 78,57\% kriteria "layak". Presentase 85,94\% kriteria "sangat layak" didpaatkan dari komponen grafik. Hasil validasi yang telah didapatkan dari beberapa ahli mendapatkan rata-rata sebesar $86,45 \%$ kriteria "sangat layak".
\end{abstract}

Kata kunci: Bahan Ajar E-Book, Berbasis Pendekatan Saintifik, Model Pengembangan 4D, Praktikum Akuntansi Perusahaan Manufaktur.

\begin{abstract}
E-book materials are the product of this study. This research is a type of development reseacrh. The e-book teaching materials used in this study use a scientific approach. The subject in this study are Manufacturing Practicum Accounting Companies, on recording and summarizing material. Some of the objectivies are to (1) Analyze how the sequence in the development of e-book teaching materials, and (2) Analyze what results from this development reseacrh. Development reseacrh took from Thiagarajan's $4 D$ model. This type of research is R\&D (Research and Development). Although, the limitation on research is that it is only carried out untill Develop. The subject of the study were several expert lecturers and one of the subjects of the manufacturing practice accounting firm. Respondents in this study were students of class XII Financial Acoounting skills program and the State Vocational School 1 Sooko Mojokerto totaling 20 students. The result of research from several experts showed several components, namely the feasibility of the content of $89,22 \%$ with the criteria of "very feasible". $92,10 \%$ with the criteria of "very feasible" obtained from the aspect of presentation. The linguistic component was obtained by a percentage of 78,57\% "feasible criteria".
\end{abstract}

Keywords: 4D Development Program, Based on Scientific Approach, E-book Teaching Materials, Manufacturing Practicum Accounting Company. 


\section{PENDAHULUAN}

Bidang ilmu pengetahuan dan teknologi (IPTEK) memiliki kemajuan yang sangat cepat dan juga memberi efek bagi berbagai aspek kehidupan. Dampak perubahan IPTEK yang paling dominan terlihat dalam bidang pendidikan. Perkembangan teknologi yang berkembang sangat cepat juga memberikan dampak bagi semua bidang kehidupan, salah satunya pendidikan (Lailiyah \& Rohayati, 2015).

Pendidikan merupakan usaha untuk mencerdaskan kehidupan bangsa, sebagaimana tertuang dalam UUD 1945 Pasal 31 Ayat 1 yang berbunyi "Setiap warga negara berhak mendapatkan pendidikan". Pendidikan adalah ilmu dan seni. Pendidikan sebagai ilmu berarti dalam usaha pendidikan seorang guru harus menguasai ilmu sehingga ia mampu memberikan ilmu tersebut kepada peserta didik. Sedangkan pendidikan sebagai seni berarti dalam proses pembelajaran setiap pendidik memiliki cara sendiri dalam melakukan tugas sebagai seorang pendidik.

Belajar merupakan kegiatan penting yang dilakukan secara maksimal oleh setiap orang untuk dapat menguasai atau memperoleh sesuatu (Nursalim, 2007). Menurut (Rivai, 2010) kegiatan belajar mengajar ialah kegiatan untuk menjalankan kurikulum yang diterapkan pada lembaga pendidikan dan diharapkan mampu mendorong peserta didik dalam menggapai tujuan pendidikan yang sudah ditentukan. Saat kegiatan belajar mengajar, pendidik diharapkan bisa memberikan ilmu dengan baik dan memberikan fasilitas pembelajaran yang baik pula, misalnya diadakan sesi bertanya yang ditujukan untuk mendorong peserta didik agar lebih berperan aktif. Sedangkan untuk peserta didik diharapkan mampu mengerti ilmu yang didapatkan dari pendidik. Hingga kegiatan belajar mengajar bisa berjalan dengan semestinya.

Akuntansi adalah bidang ilmu dapat dipelajari dengan adanya segi praktik. Tidak seperti bidang ilmu lainnya, dimana bidang imu lainnya dapat dipelajari dari segi teori saja. Program keahlian akuntansi dapat dijumpai di Sekolah Menengah Kejuruan
(SMK) ialah lembaga pendidikan yang berfokus pada peserta didik yang nantinya diterjunkan langsung pada dunia pekerjaan.

Program keahlian Akuntansi

Keuangan Dan Lembaga yang terdapat di SMKN 1 Sooko masih ditemui salah satu fenomena yang dihadapi oleh peserta didik yaitu peserta didik dirasa belum mampu memahami buku ajar yang difasilitasi oleh sekolah. Oleh karena itu, inovasi baru sangat dibutuhkan untuk bisa membantu peserta didik dalam memahami materi sebelum menyelesaikan kasus-kasus pada praktikum akuntansi perusahaan manufaktur. Salah satunya melalui pengembangan bahan ajar e-book.

Mempertimbangkan dan menentukan bahan ajar, diharuskan memenuhi syarat bahwa bahan ajar yang dikembangkan harus membuat peserta didik tertarik dan juga bisa mendorong peserta didik dalam memenuhi kompetensi. Menentukan dan membuat bahan ajar sesuai dengan yang diperlukan, dapat dijadikan pertimbangan pembuatan bahan ajar. Bahan ajar diharapkan memiliki kecocokan pada kompetensi dasar yang ada.

Pengertian bahan ajar menurut (National Centre for Competency Based) bahan ajar adalah segala bentuk bahan yang digunakan untuk membantu pendidik dalam melaksanakan proses pembelajaran dikelas. Bahan ajar ialah segala jenis bahan ajar yang memiliki fungsi bagi seorang pendidik dalam proses pembelajaran yang dilaksanakan (Hamdani, 2011). Sedangkan menurut Prastowo (2015) materi yang disusun dan dikumpulkan dari berbagai sumber dapat dikategorikan sebagai bahan atau buku ajar.

Beberapa jenis bahan ajar telah dibedakan menurut fungsinya, (1) Bahan ajar berwujud buku; (2) Bahan ajar yang digunakan melalui pendengaran;

Bahan ajar yang digunakan melalui indera penglihatan dan pendengaran; dan (4) Bahan ajar multimedia interaktif.

Dilihat dari penjelasan diatas, diperlukan suatu pengembangan untuk mendukung proses belajar mengajar peserta didik. Bahan ajar pendukung dibutuhkan haruslah bahan ajar yang memiliki inovasi 
baru, kreatif, dan menarik perhatian peserta didik dalam mendalami isi dari pencatatan dan pengikhtisaran untuk perusahaan manufaktur. Buku atau bahan ajar tidak hanya berbentuk cetak. Sesuai dengan perkembangan IPTEK, buku atau bahan ajar juga ada yang berbentuk non cetak. Bahan ajar non cetak dapat dikatakan lebih efektif dan efisie, karena mudah dibawa dan dipelajari dimana saja. Menurut Suarez (2013) berpendapat bahwasannya pengertian e-book dapat dikatakan suatu bahan ajar yang digunakan dalam pada perangkat digital dan bahan ajar digital pada umumnya memuat gambar, tulisan, dan animasi yang dapat dibaca pada perangkat elektronik. Menurut Wati (2016) berpendapat bahwa manfaat ebook ialah untuk dapat melestarikan literatur buku yang jumlahnya cukup banyak, tidak lapuk dan dapat bertahan lama karena disimpan dalam bentuk file, ebook juga memiliki sifat portable yang dapat digunakan kapan saja dan dimana saja.

Studi pendahuluan yang telah dilakukan oleh pengembang, mengatakan bahwa bahan ajar yang diperlukan ialah yang cocok dengan kurikulum 2013. Pembelajaran pada kurikulum 2013 dilakukan dengan cara melatih keterampilan proses yang tercermin dalam kegiatan pembelajaran (kemendikbud, 2014) Proses pada kegiatan belajar mengajar yang ada pada kurikulum saat ini yakni memakai saintific approach, dimana runtutan pembelajaran berpusat pada peserta didik. Pada pendekatan saintifik terdapat lima keterampilan yang biasa disebut 5M (Mengamati, Menanya, Mengumpulkan Informasi, Mengasosiasi, Mengkomunikasikan). Prinsip dari saintific approach ialah pola pembelajaran student center atau biasa disebut pembelajaran yang membuat peserta didik lebih berperan.

Berdasarkan studi pendahuluan yang menggunakan metode tanya jawab dengan guru akuntansi mata pelajaran terkait, berikut fenomena yang terjadi yaitu: 1) Siswa kelas XII yang masih kurang begitu memahami pencatatan dan pengikhtisaran perusahaan manufaktur; 2) Mata pelajaran tersebut masih memakai bahan ajar yang dimiliki oleh guru, sedangkan siswa difasilitasi buku paket oleh perpustakaan, tetapi buku pegangan yang digunakan banyak yang tidak sesuai dengan Kompetensi Dasar; dan 3) pada saat mengerjakan kasus pada praktikum akuntansi perusahaan manufaktur, siswa merasa kesulitan pada tahap pencatatan dan pengikhtisaran, dan guru hanya menghimbau mereka untuk mencari dibuku atau internet. Berdasarkan uraian diatas, dibutuhkan alternatif dan solusi untuk mengatasi fenomena pembelajaran yang ada. Karenanya, pengembang mencoba mengembangkan bahan ajar yang berjudul "Pengembangan Bahan Ajar E-Book Pada Mata Pelajaran Praktikum Akuntansi Perusahaan Manufaktur Kelas XII Program Keahlian Akuntani Keuangan Dan Lembaga SMK Negeri 1 Sooko Mojokerto".

Rumusan masalah yang terdapat pada penelitian ini (1) Bagaimana runtutan atau proses pengembangan bahan ajar e-book yang dilakukan di SMKN 1 Sooko Mojokerto?; (2) Bagaimanakah kualitas bahan ajar e-book yang dikembangkan di SMKN 1 Sooko Mojokerto?.

Ada beberapa tujuan yang dilakukan pada penelitian pengembangan, diantaranya (1) Mengetahui bagaimana runtutan pengembangan bahan ajar e-book. (2) Mengetahui kualitas hasil pengembangan bahan ajar e-book di SMKN 1 Sooko Mojokerto.

Pada penelitian Fitriani (2019) dengan judul "Pengembangan E-Book Berbasis Android Dengan Pendekatan Saintifik Pada Mata Peljaran Administrasi Pajak Kelas XII Akuntansi Di SMK Negeri 2 Buduran". Penelitian tersebut menghasilkan e-book yang telah divalidasi oleh beberapa ahli sebesar $84,71 \%$ dengan kriteria sangat layak. Hasil uji coba pada siswa mendapatkan 90,90\% kriteria sangat layak. Penelitian ini memiliki persamaan dengan penelitian yang saya lakukan yaitu mengembangkan e-book sebagai bahan ajar dan menggunakan pendekatan saintifik. Perbedaannya terletak pada materi yang digunakan. Pada penelitian ini membahas tentang mata pelajaran administrasi pajak. Sedangkan penelitian 
saya membahas tentang matrei harga pokok pesanan dan proses pada metode perpetual.

Selanjutnya pada penelitian Fadhilah (2019) berjudul "Pengembangan Buku Ajar Akuntansi Berbasis Scientific Approach Pada Materi Proses Pencatatan Dan Pengikhtisaran Perusahaan Manufaktur Mata Pelajaran Akuntansi Dasar Kelas X Akuntansi Dan Keuangan Dan Lembaga SMK Negeri 1 Bangkalan". Hasil penelitian yang telah divalidasi oleh para ahli mendapatkan ratarata sebesar $82,46 \%$ dengan kriteria sangat layak. Penelitian ini memiliki persamaan dengan penelitian yang saya lakukan yaitu melakukan pengembangan bahan ajar pada matrei perusahaan manufaktur. Sedangkan perbedaannya terletak pada mata poelajaran. Pada penelitian ini menggunakan mata pelajaran akuntansi dasar kelas X, sedangkan peneitian saya pada mata pelajaran praktikum akuntansi perusahaan manufaktur kelas XII.

Dari latar belakang yang sudah dijelaskan diatas, pengembang dapat menyusun penelitian yang berjudul "Pengembanan Bahan Ajar E-Book Pada Mata Pelajaran Praktikum Akuntansi Perusahaan Manufaktur Kelas XII Program Keahlian Akuntansi Keuangan Dan Lembaga SMK Negeri 1 Sooko Mojokerto".

\section{METODE PENELITIAN}

Penelitian pengembangan menggunakan pola 4D (Thiagarajan, 1974). Metode penelitian pada dasarnya merupakan cara ilmiah untuk mendapatkan data dengan tujuan dan kegunaan tertentu (Sugiyono, 2015). Kegiatan yang diteliti termasuk jenis penelitian dan pengembangan (Reseacrh and Development). Terdapat 4 tahapan dalam pola penelitian ini yakni Define, Design, Develop, Disseminate (Thiagarajan, 1974). Tetapi penelitian ini hanya sebatas pada tahap Develop. Berikut gambar 1 merupakan gambaran prosedur pengembangan bahan ajar e-book pada penelitian ini.

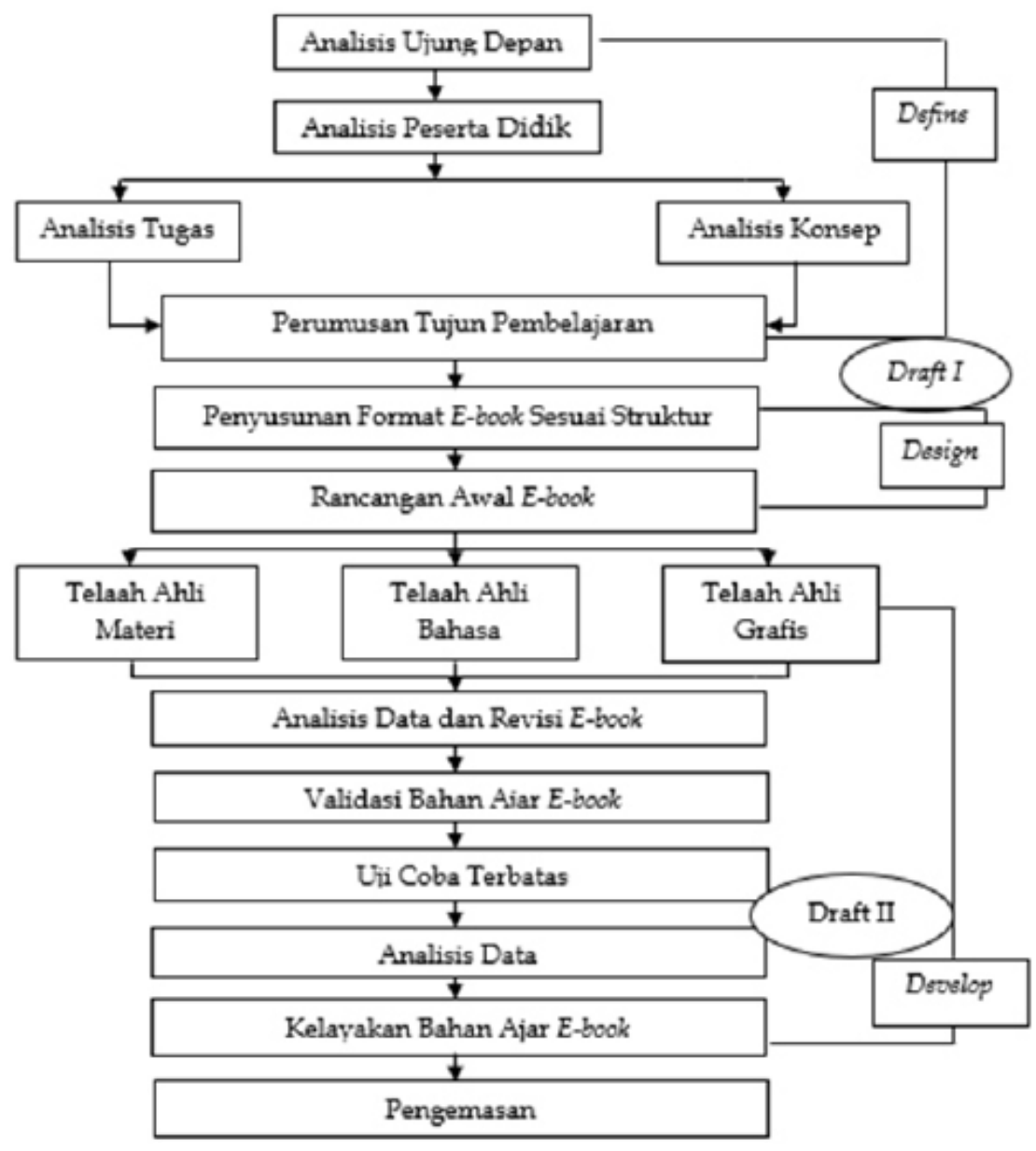

Gambar 1. Prosedur penelitian pengembangan bahan ajar e-book model 4D Thiagarajan (Trianto, 2015) 
Subjek uji coba pada penelitian ini ialah ahli materi yang terdiri dari salah satu dosen Pendidikan Akuntansi Fakultas Ekonomi UNESA dan salah satu guru mata pelajaran praktikum akuntansi perusahaan manufaktur SMK Negeri 1 Sooko Mojokerto. Ahli bahasa ialah salah satu dosen Sastra Indonesia Fakultas Bahasa dan seni UNESA. Ahli grafis ialah salah satu dosen Teknologi Pendidikan Fakultas Ilmu Pendidikan UNESA. Subjek penelitian tidak dipilih random melainkan secara claster random untuk dilibatkan dalam dua kelompok kelas eksperimen (Setyosari, 2015).
Pada analisis data terdapat analisis deskriptif dan kuantitatif. Teknik analisis data tersebut menghasilkan (1) Teknik analisis data dari beberapa ahli, berisi masukan dan saran yaitu teknik analisis data secara deskriptif; (2) Data analisis diperoleh melalui hasil validator beberapa ahli (ahli materi, bahasa, dan grafis) yang diperoleh dari perhitungan skor penilaian yang didapatkan dilembar validasi beberapa ahli didapatkan dari perhitungan skala liekrt; dan (3) Data dari responden yaitu peserta didik didapatkan dari menyebar angket respons pada peserta didik. Data tersebut akan dilakukan perhitungan memakai skala Guttman.

Tabel 1. Penilaian validasi para ahli menggunakan skala likert

\begin{tabular}{cc}
\hline Kriteria & Skor \\
\hline Sangat Layak & 5 \\
\hline Layak & 4 \\
\hline Cukup Layak & 3 \\
\hline Tidak Layak & 2 \\
\hline Sangat Tidak Layak & 1 \\
\hline
\end{tabular}

Sumber: (Riduwan, 2016)

Kemudian hasil validasi dianalisis memakai perhitungan pada rumus berikut. Sumber

(Riduwan, 2016)

$$
\text { Presentase Kelayakan }=\frac{\text { Jumlah skor keseluruhan }(\mathrm{X})}{\text { Skor paling tinggi }(X i)} \times 100 \%
$$

Keterangan :

Jumlah Skor Keseluruhan = Total jumlah skor yang diperoleh dari responden

Skor paling tinggi $\quad=$ Skor maksimal tiap item soal $\mathrm{x}$ jumlah responden

Tabel 2. Kriteria Interpretasi Skor

\begin{tabular}{lc}
\hline Penilaian & Kriteria \\
\hline $81 \%-100 \%$ & Sangat Layak \\
\hline $61 \%-80 \%$ & Layak \\
\hline $41 \%-60 \%$ & Cukup Layak \\
\hline $21 \%-40 \%$ & Tidak Layak \\
\hline $0 \%-20 \%$ & Sangat Tidak Layak \\
\hline
\end{tabular}

Sumber: Riduwan, 2016

Teknik analisis data dari lembar respon yaitu analisis data deskriptif akan dihitung memakai skala Guttman dan kuantitatif berupa presentase. Data tersebut memiliki rincian seperti tabel 3 berikut.

Tabel 3. Ketentuan penilaian skala Guttman

\begin{tabular}{cc}
\hline Jawaban & Skor \\
\hline Ya & 1 \\
\hline Tidak & 0 \\
\hline Sumber: Riduwan, 2016
\end{tabular}


Perhitungan skor penilaian dengan sebagai berikut. Sumber: Riduwan (2016) perhitungan presentase dengan rincian

$$
\text { Presentase Kelayakan }=\frac{\text { Jumlah skor keseluruhan }(\mathrm{X})}{\text { Skor paling tinggi }(\mathrm{Xi})} \times 100 \%
$$

Keterangan

Jumlah Skor Keseluruhan $=$ Total jumlah skor yang diperoleh dari responden

Skor paling tinggi $\quad=$ Skor maksimal tiap item soal $\mathrm{x}$ jumlah responden

Selanjutnya yaitu penginterpretasian skor sebagai berikut.

penilaian kelayakan dengan ketentuan

Tabel 4. Interpretasi Skor Respon Peserta Didik

\begin{tabular}{cc}
\hline Presentase & Kriteria Interpretasi \\
\hline $0 \%-20 \%$ & Sangat Tidak Memahami \\
\hline $21 \%-40 \%$ & Tidak Memahami \\
\hline $41 \%-60 \%$ & Cukup Memahami \\
\hline $61 \%-80 \%$ & Memahami \\
\hline $81 \%-100 \%$ & Sangat Memahami \\
\hline
\end{tabular}

Sumber: Riduwan, 2016

\section{HASIL DAN PEMBAHASAN}

\subsection{Hasil}

Proses dalam mengembangkan bahan ajar e-book yang terdapat pada penelitian ini berpedoman pada model pengembangan 4D Thiagarajan. Terdapat empat tahap yaitu Define, Design, Develop, dan Dessiminate.

Pada proses Define (Pendefinisian) peneliti dapat menentukan kebutuhan peserta didik pada proses belajar mengajar, selain itu peneliti diharapkan mampu menggali lebih dalam lagi mengenai informasi produk yang akan dikembangkan. Define terdiri dari beberapa tahapan yaitu analisis ujung depan; analisis peserta didik; analisis tugas; analisis konsep; perumusan tujuan pembelajaran.

Selanjutnya ialah proses analisis ujung depan dengan cara studi pendahuluan yang memiliki tujuan yaitu mengidentifikasi dan menentukan fenomena yang dihadapi oleh siswa pada saat pembelajaran berlangsung. Sehingga membutuhkan sebuah bahan ajar tambahan yang mampu mendukung proses belajar mengajar.

Proses analisis peserta didik dilakukan bertujuan agar peneliti mengerti karakteristik peserta didik. Diantaranya ialah peserta didik belum sepenuhnya berperan dalam proses belajar mengajar, karena buku pegangan yang difasilitasi oleh sekolah belum sesuai dengan kompetensi dasar. Peserta didik membutuhkan bahan ajar tambahan yang menarik belajar mereka dan juga memotivasi mereka agar terus berkeinginan untuk mempelajari mata pelajaran praktikum akuntansi, khususnya pada pencatatan dan pengikhtisaran. Dengan dikembangkannya bahan ajar e-book, pengembang berharap peserta didik mampu memenuhi tujuan pembelajaran yang ada dan juga menerapkan kurikulum 2013 yang didalamnya terdapat pendekatan saintifik yang menuntut peserta didik ikut serta dalam proses pembelajaran (student center).

Analisis tugas bertujuan untuk membantu peneliti agar dapat menentukan tugas yang akan diberikan pada peserta didik. Didapatkan dari analisis tugas dapat dirumuskan bahwa tugas yang bisa diberikan ialah tugas yang berisi pertanyaanpertanyaan yang mengandung HOTS (High Order Thingking Skill).

Tujuan yang terdapat analisis konsep bertujuan untuk menentukan isi bahan ajar pada e-book yang dikembangkan. Dengan adanya bahan ajar e-book ini harapannya mampu memeprmudah peserta didik dalam mendalami praktikum akuntansi pada 
khususnya perusahaan manufaktur. Isi dari bahan ajar e-book ini yakni terdiri dari kompetensi dasar 3.20-3.27 yang mencakup materi pencatatan dan pengikhtisaran.

Tujuan dari perumusan pembelajaran agar dapat menentukan indikator yang nanti akan disesuaikan dengan kompetensi dasar dan kompetensi inti. Hasil yang didapat nanti akan diajdikan sebagai dasar dalam menyusun bahan ajar e-book.

\subsection{Pembahasan}

a. Tahap Perancangan Bahan Ajar E-Book

Peneliti mendesain bahan ajar yang telah disesuaikan dengan kurikulum 2013 yang saat ini diterapkan. Bahan ajar e-book berisikan materi pada KD 3.20-3.27 yang telah disebutkan sebelumnya. Format bahan ajar e-book yang digunakan berpedoman pada struktur BSNP2014 dan telah dimodifikasi oleh peneliti. Selanjutnya tahap perancangan awal e-book dilakukan dengan menggabungkan rancangan awal e-book menjadi satu kesatuan hingga diperoleh draft 1 .

\section{b. Tahap Pengembangan Bahan Ajar E-book}

Tahap pengembangan terdiri dari telaah para ahli yaitu ahli materi, ahli bahasa, dan ahli grafis. Telaah ialah sebuah proses mengkaji secara mendalam yang dilkaukan oleh para ahli terhadap produk pada penelitian pengembangan. Telaah yang dilakukan oleh ahli materi ialah Bapak Drs.Joni Susilowibowo, M.Pd selaku dosen pengampu mata kuliah praktikum akuntansi Fakultas Ekonomi UNESA dan Ibu Dra. Zulfatus Sholichah, M.Pd selaku guru mata pelajaran praktikum akuntansi perusahaan manufaktur Kelas XII Akuntansi Keuangan dan Lembaga SMK Negeri 1 Sooko Mojokerto yang memberikan masukan dan saran terkait pengembangan bahan ajar e-book pada prakitkum akuntansi perusahaan manufaktur agar menjadi lebih baik. Penelaah ahli Bahasa ialah Bapak Dr.Mulyono, M.Hum selaku dosen Pendidikan Bahasa dan Sastra Indonesia UNESA memberikan masukan dan saran perihal penggunaan kata dan juga bahasa yang digunakan dalam bahan ajar e-book agar menjadi lebih baik. Telaah grafis ialah Bapak Dr. Fajar Arianto, M.Pd selaku dosen Teknologi Pendidikan Fakultas Ilmu Pendidikan UNESA memberikan masukan dan saran terkait tata letak logo dan nama penulis pada sampul depan, kekontrasan warna dan tata letak penulisan agar menjadi lebih baik lagi.

c. Kelayakan Bahan Ajar E-Book

Materi pencatatan dan pengikhtisaran pada perusahaan manufaktur ialah isi yang terdapat pada kelayakan produk penelitian. Materi yang ada ialah hasil dari analisis validasi dari beberapa ahli. Beberapa ahli tersebut memberikan menilai dari bahan ajar e-book ialah ahli materi, bahasa, dan grafis. Kriteria penilaian dapat mempengaruhi kalyakan bahan ajar yaitu kelayakan penyajian, kebahasaan dan grafis.

Aplikasi yang digunakan dalam mengembangkan bahan ajar e-book ini ialah aplikasi 3D flipbook dimana aplikasi tersebut hanya dapat digunakan pada perangkat komputer atau laptop, buku digital yang diolah didalam software akan diinput dalam bentuk pdf, video ataupun media yang dimasukkan dalam buku digital tidak dapat dipisahkan dari menu utama. Selain itu, aplikasi $3 D$ flipbook juga memiliki kelebihan diantaranya dapat mengimpor berbagai pilihan menjadi halaman balik buku flip, gambar, film import dan video, menyesuaikan tampilan output, dan format output dapat fleksibel berupa SWF, exe, HTML atau ZIP.

Tabel 5. Rekapitulasi Hasil Validasi Para Ahli

\begin{tabular}{cccc}
\hline No & Aspek & Presentase & Kriteria \\
\hline 1 & Isi materi & $89,22 \%$ & Sangat Layak \\
\hline 2 & Penyajian & $92,10 \%$ & Sangat Layak \\
\hline 3 & Bahasa & $78,57 \%$ & Layak \\
\hline 4 & Kegrafikan & $85,94 \%$ & Sangat Layak \\
\hline Rata-rata & $\mathbf{8 6 , 4 5 \%}$ & Sangat Layak \\
\hline
\end{tabular}


Bersumber dari keterangan tabel 5 yang telah di olah oleh peneliti, bagian aspek isi materi mendapatkan presentase sebesar $89,22 \%$ dan mendapatkan kriteria "Sangat Layak". Bahan ajar e-book telah mencakup kompetensi pengetahuan dan keterampilan, dan telah disesuaikan dengan perangkat pembelajaran yang berlaku. Presentase yang didapatkan dari komponen penyajian sebesar 92,10\% dengan kriteria "Sangat Layak". Materi yang disajikan didukung dengan adanya fitur video pengamatan, growth caracter yang ditujukan untuk meningkatkan motivasi belajar peserta didik. Terdapat soal uji kompetensi yang telah dicocokkan dengan model soal HOTS (High Order Thingking Skill) yang dapat membantu kemampuan peserta didik dalam berpikir kritis. Komponen kebahasaan mendapatkan presentase sebesar $78,57 \%$ dengan kriteria "Layak". Bahasa yang ada didalam bahan ajar e-book yang dikembangkan ini sangat mudah dipahami, selain itu juga dapat memberikan motivasi kepada peserta didik. Presentase 85,94\% dengan kriteria "Sangat Layak" didapat dari komponen kegrafikan (BSNP, 2014), bagian yang terdapat pada bahan ajar telah disusun secara proporsional dan telah sesuai dengan yang dibutuhkan oleh peserta didik. Desain yang terdapat pada bahan ajar e-book sengaja dibuat menarik agar bisa membangkitkan perhatian peserta didik, hingga peserta didik dapat meningkatkan minat belajar. Hasil yang diperoleh mendapatkan rata-rata sebanyak 86,94\% kriteria "Sangat Layak". Maka dapat dikatakan bahan ajar e-book pada matrei pencatatan dan pengikhtisaran praktikum akuntansi perusahaan manufaktur kelas XII di SMKN 1 Sooko Mojokerto yang dikembangkan pada penelitian ini dikatakan sangat layak dipakai.

\section{KESIMPULAN}

Bersumber hasil penelitian pada bab sebelumnya, dapat disimpulkan bahwa 1) Pengembangan bahan ajar e-book menggunakan model pengembangan 4D Thiagarajan yang terdiri dari empat tahap yaitu Define (Pendefinisian), Design (Perancangan), Develop (Pengembangan), dan Dessiminate (Penyebaran); dan 2) Model pengembangan pada penelitian ini bertujuan untuk memperoleh kelayakan pada pengembangan bahan ajar e-book. Sehingga akan didapatkan hasil validasi dari penilaian bahan ajar e-book yang dilakukan oleh beberapa ahli yang disesuaikan dengan kriteria kelayakan dimana meliputi kelayakan isi, penyajian, kebahasaan, dan kegrafikan (BSNP, 2014). Beberapa ahli yang melakukan valiidasi bahan ajar e-book ialah ahli materi, ahli bahasa, dan ahli grafis, dengan jumlah rata-rata kelayakan mendapatkan kriteria "sangat layak".

\section{DAFTAR PUSTAKA}

BNSP. (2014). Naskah Akademik Instrumen Kelayakan Kegrafikan. Jakarta: BNSP.

BSNP. (2014). Naskah Akademik Instrumen Penialaian Buku Teks Kelayakan Kegrafikan. Jakarta: BSNP.

Departermen Pendidikan Nasional. (2003). Undang- Undang Republik Indonesia No. 20 Tahun 2003 Tentang Sistem Pendidikan Nasional. Jakarta: Departermen Pendidikan Nasional.

Dewi, D. R, \& Suci, R. (2012). Pengembangan Bahan Ajar E-Book Interaktif Materi Jurnal Khusus Akuntansi Perusahaan Dagang Berbasis Scientific Approach Sebagai Sumber Belajar Alternatif Kelas XI SMK Negeri 2 Buduran Sidoarjo. Jurnal Pendidikan Akuntansi (JPAK), 5(2).

Fitriani, I. (2019). Pengembangan E-Book Berbasis Android Dengan Pendekatan Saintifik Pada Mata Pelajaran Administrasi Pajak Kelas Xii Akuntansi Di Smk Negeri 2 Buduran. Pendidikan Akuntansi, 7, 1-10.

Fadhilah, N. (2019). Pengembangan buku ajar berbasisscientific approach pada materi proses pencatatan dan pengikhtisaran perusahaan manufaktur mata pelajaran akuntansi dasar kelas $\mathrm{X}$ akuntansi keuangan dan lembaga SMK negeri 1 Bangkalan. Jurnal Pendidikan Akuntansi, 7, 372-377.

Hamdani. (2011). Strategi Belajar Mengajar. Bandung: CV Pustaka Setia.

Kemendikbud. (2014). Permendikbud Nomor 60 Tahun 2014. Jakarta: Peraturan Kementrian Pendidikan dsn Kebudayaan.

Lailiyah, R. I., \& Rohayati, S. (2015). Pengembangan media pembelajaran berbasis adobe flash CS6 pada materi jurnal penyesuaian perusahaan dagang kelas X-AK SMK Muhammadiyah 1 Taman. Jurnal Pendidikan 
Akuntansi (JPAK), 3(1).

Nursalim, M. D. (2007). Psikologi Pendiidkan. Unesa University Press.

Riduwan. (2016). Skala Pengukuran variabel variabel penelitian. Bandung: ALFABETA.

Prastowo, A. (2015). Panduan Kreatif Membuat Bahan Ajar Inovatif. Yogyakarta: DIVA Press.

Rivai, S. dan. (2010). Media Pengajaran. Bandung: Sinar Baru Algensindo.

Setyosari, P. (2015). Metode Penelitian Pendidikan dan Pengembangan. Malang: PRANEDAMEDIA Group.

Suarez , M. F. W. (2013). The Book a Global History. Oxford: Oxford University Press.

Sugiyono. (2015). Metode Penelitian dan pengembangan. Yogyakarta: Alfabeta Bandung.

Trianto. (2015). Mendesain Model Pembelajaran Inovatif dan Kontekstual. Jakarta: Kencana Prenada Media Group.

Thiagarajan, S., Semmel, D. S., \& Semmel, M. I. (1974). Instructional Development for Training Teachers of Exceptional Children: A Sourcebook. Indiana: Indiana University.

Wati, E. R. (2016). Ragam Media Pembelajaran. Jakarta: Kata Pena. 